Research article

UDK: 636.7.09:616.993.1-074

DOI: $10.2478 /$ acve-2021-0014

\title{
RELATIONSHIP BETWEEN CHANGES IN HEMATOLOGICAL PARAMETERS, LEVELS OF ACUTE PHASE PROTEINS AND REDOX HOMEOSTASIS DURING ACUTE BABESIA CANIS INFECTION IN DOGS
}

\author{
Kristina SPARIOSU1*, Filip JANJIĆ ${ }^{1}$, Jelena FRANCUSKI ANDRIĆ ${ }^{1}$, \\ Milena RADAKOVIĆ ${ }^{1}$, Anđelo BELETIĆ ${ }^{2}$, Milica KOVAČEVIĆ FILIPOVIĆ ${ }^{1}$, \\ Svetlana MILANOVIĆ
}

${ }^{1}$ Faculty of Veterinary Medicine, University of Belgrade, Bulevar oslobođenja 18, Belgrade, Serbia

${ }^{2}$ Center for Medical Biochemistry, University Clinical Center of Serbia, Višegradska 26, Belgrade, Serbia

(Received 02 April, Accepted 24 May 2021)

\begin{abstract}
Hemolysis and systemic acute inflammation characterize canine babesiosis caused by the intraerythrocytic protozoan parasite Babesia canis. Our hypothesis was that blood redox homeostasis of patients that suffered acute B. canis infection might be disturbed even after treatment with imidocarb-dipropionate and successful clinical recovery. Eight owner dogs with acute B. canis infection were used for this study. We analyzed the complete blood count, acute phase proteins (ceruloplasmin, haptoglobin, paraoxonase-1) in the serum, antioxidant enzymes (catalase and glutathione peroxidase) in the erythrocytes, and oxidative stress markers (malondialdehyde in erythrocytes and thiol groups in serum) at presentation and 15 days after treatment. Results were evaluated by corresponding statistical tests. At presentation, anemia, low/normal leukocyte count and severe thrombocytopenia occurred together with increased ceruloplasmin, haptoglobin levels within the reference interval, decreased paraoxonase-1 and compromised antioxidant defense in the red blood cells. After treatment and successful clinical recovery, hematological values generally fitted within the reference intervals, acute phase proteins were within the physiological levels in the majority of cases and the activities of the antioxidant enzymes were increased. However, elevated malondialdehyde levels indicated increased oxidative damage of erythrocytes that remained as a deleterious sequel despite a successful clinical recovery of the dogs.
\end{abstract}

Key words: acute phase proteins, babesiosis, erythrocytes, inflammation, oxidative stress

\section{INTRODUCTION}

Babesia canis is a protozoan parasite which, upon invading red blood cells (RBCs), initiates events that ultimately lead to accelerated intravascular or extravascular hemolysis and

*Corresponding author: e-mail: eevermcteen@gmail.com, kristina@vet.bg.ac.rs 
vigorous acute phase response (APR) [1]. Babesia spp. damage the erythrocytes and the factors involved are diverse: anti-erythrocyte antibodies, IgG-bound erythrocytes, phagocytosis, osmotic fragility, erythrocyte oxidative injury and structural membrane changes [2]. Several reports indicate the importance of disturbed redox homeostasis in the pathogenesis of protozoan diseases [3-5]. In ovine theileriosis, lipid peroxidation of RBCs' membranes leads to increased levels of malondialdehyde (MDA) and decreased activity of antioxidant enzymes [6]. Furthermore, upon invasion of dogs' RBCs by B. gibsoni, methemoglobin and MDA formation were elevated [7]. Finally, the overall oxidative stress in dogs with acute B. canis infection can determine the outcome of the disease [8].

During the APR, balance in pro-inflammatory and anti-inflammatory cellular and humoral factors acts to restore the tissue structure and function [9]. Thus, activated neutrophils and monocytes eliminate the pathogens, but also generate an excess of reactive oxygen species (ROS) $[10,11]$. Acute phase proteins (APPs) like ceruloplasmin (CER) and paraoxonase-1 (PON-1) neutralize ROS and protect different tissue structures $[12,13]$. In addition, haptoglobin (HPT) removes free hemoglobin from the blood and prevents iron-driven oxidative damage [14]. Both acute and asymptomatic B. canis infections are characterized by CER levels above and PON-1 levels below the reference interval $[15,16]$. HPT concentration also changes in the course of $B$. canis infection reflecting the hemolytic and inflammatory nature of the disease [17]. Although it was previously shown that dogs with acute B. canis infection have low antioxidant defense and high MDA values [8], as well as increased APPs [15], a more comprehensive research about long-term consequences on redox homeostasis in RBCs and plasma/serum has not been done.

We hypothesized that due to the dogs' RBCs life span up to more than 100 days [18], blood redox homeostasis of patients that suffered acute B. canis infection might be disturbed for a longer period of time. The aim of this study was to investigate the relationship between hematological parameters, levels of APPs and markers of oxidative injury in RBCs and serum at presentation and 15 days after repeated treatment with imidocarb-dipropionate, i.e. at clinical recovery.

\section{MATERIALS AND METHODS}

\section{Animals}

The study included eight owner dogs that were proven positive for B. canis infection and recruited for the purpose of our previous study regarding levels of the promatrix metalloproteinases during acute B. canis infection. Dogs had clinical signs consistent with Babesia spp. infection, large Babesia forms in the blood smears and positive PCR test for B. canis. Dogs were not included if proven positive for the modified Knott test or had visible wounds, diagnosed allergy, endocrinopathies or neoplasms [19]. Complete blood count $(\mathrm{CBC})$ was performed at presentation and dogs received the first dose of imidocarb-dipropionate (6 mg/ kg of body weight, s.c.). After two weeks, CBC was 
repeated and an identical dose of imidocarb-dipropionate was readministered. The results obtained on the first day were shown under "presentation" and those measured two weeks later under "recovery". The exact number of samples is indicated in figures and tables as the quantity of some samples was insufficient for complete analysis.

The owners signed an informed consent allowing residual samples and the obtained results to be used for scientific purposes. This research was approved by the Ethical Committee, Faculty of Veterinary Medicine (University of Belgrade, Serbia). The permission was acquired from the Ministry of Agriculture, Forestry and Water Management, Republic of Serbia (permission number: 323-07-03455/2015-05/3), based on the Serbian Law of Animal Welfare.

\section{Blood sampling and hematology analysis}

Blood samples were collected in EDTA and sera tubes. CBC was performed using Abacus Junior Vet analyzer (Diatron, Wien, Austria). Peripheral blood smears were used to confirm the presence of large Babesia forms. Part of the EDTA blood was separated to prepare RBCs samples, by washing at equal volume with $0.9 \%$ sodium chloride. Isolated erythrocytes were stored at $-20^{\circ} \mathrm{C}$. The rest of the EDTA blood was frozen and sent on dry-ice to IDEXX Laboratories (Westbrook, Maine, USA) for PCR analysis. Serum tubes were centrifuged at $1500 \mathrm{~g}$ for 10 minutes and samples were stored at $-20^{\circ} \mathrm{C}$ until analyses were performed.

\section{Acute-phase proteins}

Levels of APPs were measured in the serum. Concentration of CER was measured upon its $p$-phenylenediamine (PPD) oxidase activity according to Ceron and Martinez-Subiela (2004) [20]. The method using peroxidase activity of haptoglobinhemoglobin (HPT-HGB) complex was assessed to measure the HPT level [21,22]. Spectrophotometric method with 4-nitrophenil acetate as the substrate was used to determine PON-1 activity [23].

\section{Oxidative stress and antioxidant protection parameters}

Isolated RBCs were hemolyzed and 10× diluted with distilled water before each procedure, except for the evaluation of glutathione peroxidase (GPx). Hemoglobin concentration $(\mathrm{Hgb})$ was measured by method of van Kampen and Zijlstra (1961) [24]. Catalase (CAT) activity in hemolysates was determined according to the method described by Aebi (1984) [25]. GPx activity was evaluated in the hemolysates obtained using Drabkin's reagent, by the coupled test described by Günzler et al. (1974) [26]. Lipid peroxidation was quantified via MDA levels in the hemolysates, using the method based on the formation of thiobarbituric acid reactive substances (TBARS) [27]. The level of thiol groups (THIOLS) in sera samples was measured according to the Ellman's method (1959) with 5,5'-dithiobis-(2-nitrobenzoic acid) (DTNB) [28]. Cecil CE 2021 UV/VIS was used for complete spectrophotometric analysis. 


\section{Molecular analysis}

Real-time PCR method, targeting the Hsp70 gene, was applied to confirm that the large Babesia organisms detected in the blood smears were B. canis. Analysis was performed at a commercial veterinary reference laboratory (IDEXX Laboratories, Inc.) using commercial kits (Tick/Vector Comprehensive Real PCR Panel Canine, IDEXX Laboratories, Inc.).

\section{Statistical analysis}

The significance of differences in the results between presentation and clinical recovery was evaluated using the Wilcoxon test for paired samples. Relative changes of parameters $(\%)$ were calculated as [(value at recovery - value at presentation)/value at presentation] $\times 100$. Spearman's rank correlation analysis was applied to test the significance of the relationship between values at presentation, recovery and relative changes. All analyses were performed using MedCalc ${ }^{\circledR}$ software version 16.2.1.

\section{RESULTS}

Dogs with acute B. canis infection had moderate anemia at presentation (Figure 1.AC). Number of RBCs, level of hematocrit (HCT) and whole blood hemoglobin concentration (HGB) nearly doubled at recovery, thus returning into the reference interval in the majority of dogs (Figure 1.A-C). Total leukocytes, neutrophil and lymphocyte count were lower at presentation than at the recovery (Figure 1.D-F), while monocyte count did not differ between two points (Figure 1.G). All dogs had severe thrombocytopenia at presentation and the majority of them (6/8) restored the thrombocyte count within the reference interval two weeks after treatment (Figure 1.H).

The concentration of CER was above the reference interval at presentation and decreased thereafter (Figure 2.A). The concentration of HPT remained constant in the two investigated points (Figure 2.B), while PON-1 activity was lower at presentation compared to the recovery (Figure 2.C).

The activity of CAT in RBCs was lower in the samples taken at presentation compared to those at clinical recovery (Figure 3.A), while GPx activity did not differ between these two points (Figure 3.B). The level of MDA in RBCs increased between presentation and recovery (Figure 3.C). There was no significant difference between the concentration of serum THIOLS measured at presentation and recovery (Figure 3.D).

At presentation, a strong positive correlation existed between GPx activity and MDA concentration in RBCs, and concentration of HPT in serum and HGB level in the whole blood. Serum THIOLS and total leukocyte count were in a strong negative correlation (Table 1). 

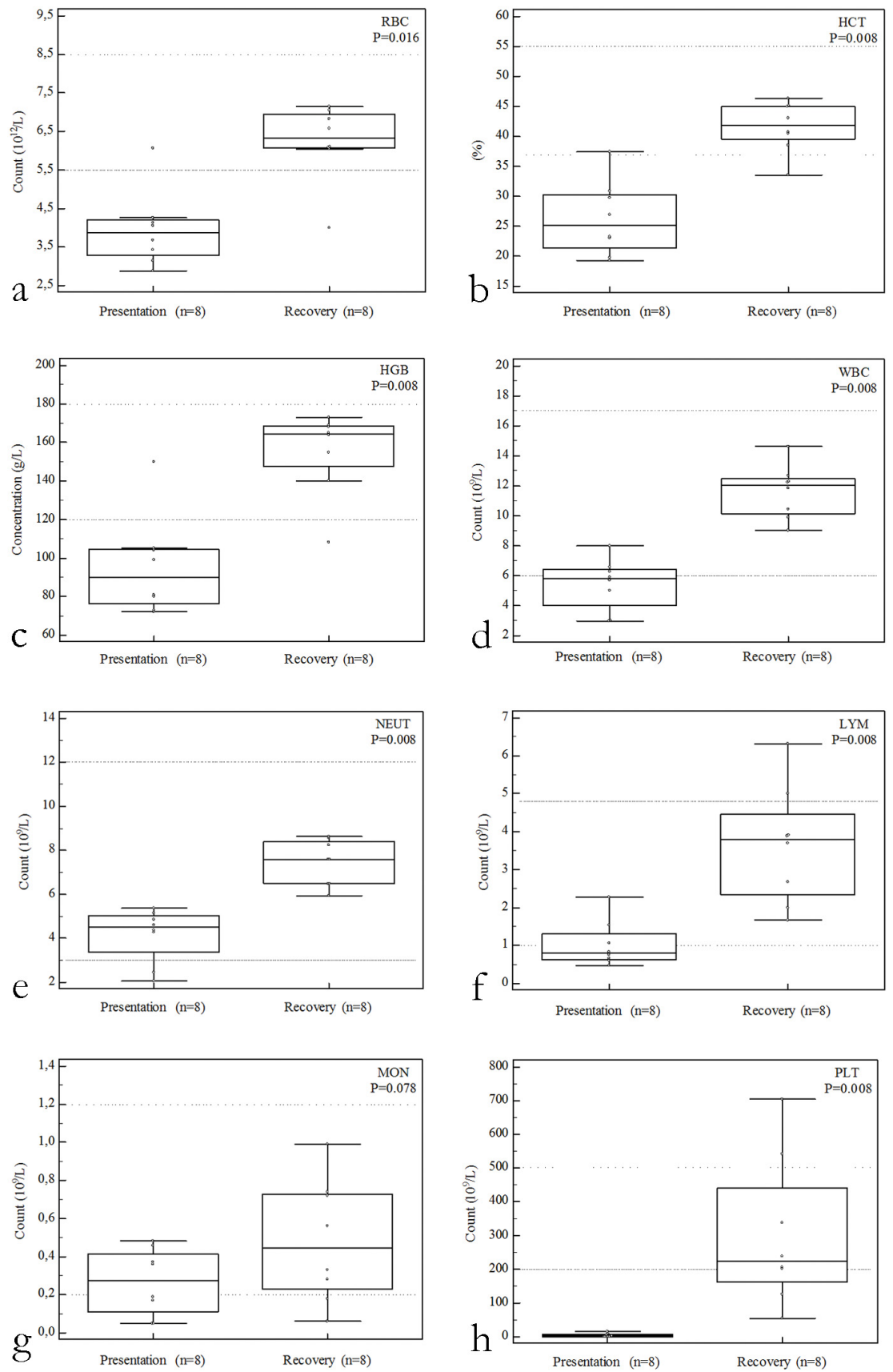

Figure 1. Count of $(\mathbf{A})$ red blood cells $(\mathrm{RBC}),(\mathrm{B})$ hematocrit $(\mathrm{HCT})$ value, $(\mathbf{C})$ concentration of hemoglobin in whole blood (HGB), count of (D) white blood cells (WBC), (E) neutrophils (NEUT), (F) lymphocytes (LYM), (G) monocytes $(\mathrm{MON})$ and $(\mathbf{H})$ platelets (PLT). Wilcoxon test, $\mathrm{P}<0.05$ is considered significant. Box represents values from lower to upper quartile. The middle line in the box represents the median. A line extends from the minimum to the maximum value. The dotted line represents reference values - Clinical laboratory, Faculty of Veterinary Medicine, University of Belgrade, Serbia 

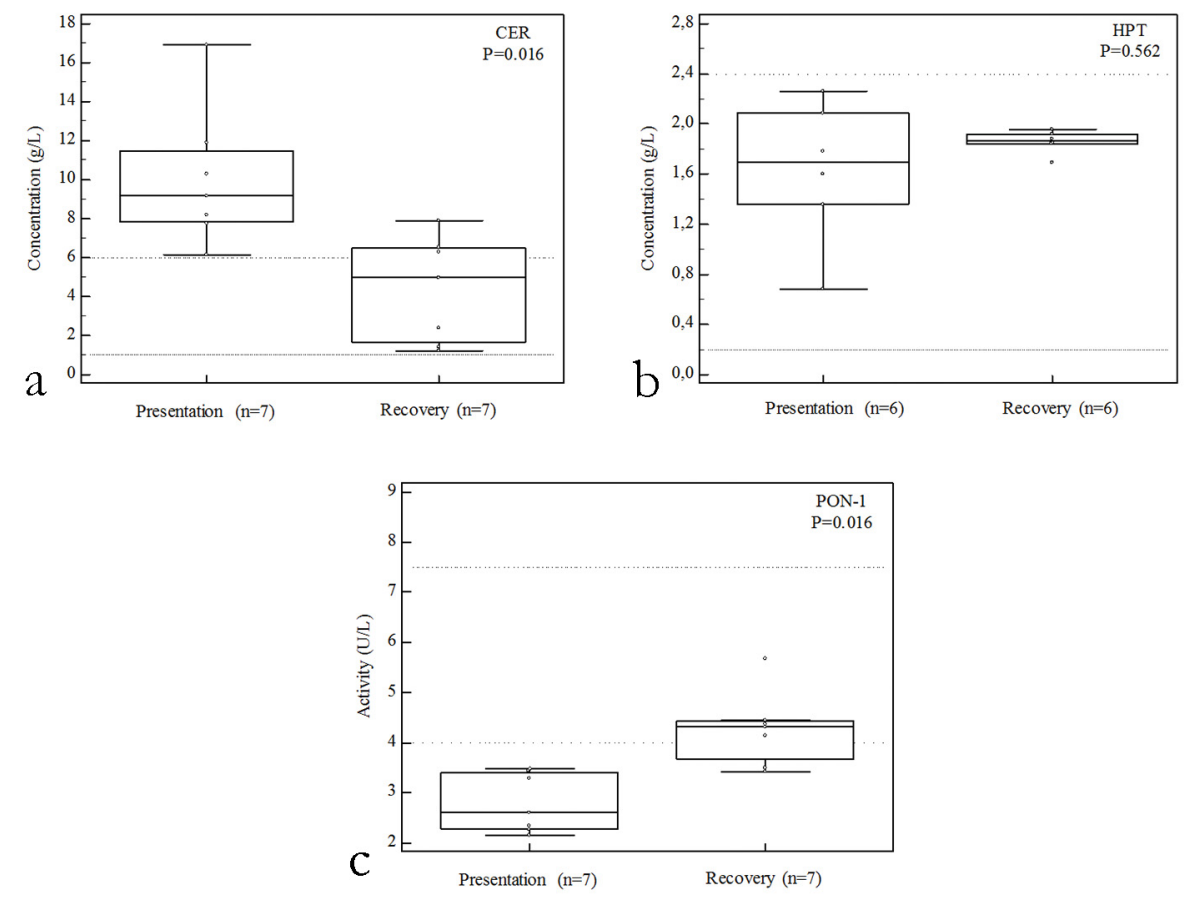

Figure 2. Concentration of (A) ceruloplasmin (CER), (B) haptoglobin (HPT) and activity of (C) paraoxonase-1 (PON-1) in sera samples. Wilcoxon test, $\mathrm{P}<0.05$ is considered significant. Box represents values from lower to upper quartile. The middle line in the box represents the median. A line extends from the minimum to the maximum value. The dotted line represents reference values - Clinical laboratory, Faculty of Veterinary Medicine, University of Belgrade, Serbia

Table 1. Relationship between the examined parameters: Spearman's coefficient of rank correlation (e), $95 \%$ confidence interval (CI). P $<0.05$ is considered significant. Number of samples in superscript, italic.

\begin{tabular}{lcc}
\hline Parameters & $\boldsymbol{Q}(\mathbf{9 5} \% \mathbf{C I})$ & P-value \\
\hline Presentation & & \\
GPx $(\mu \mathrm{Kat} / \mathrm{g} \mathrm{HGB})$ and MDA $(\mu \mathrm{mol} / \mathrm{g} \mathrm{HGB})$ & $0.810^{8}(0.244$ to 0.964$)$ & 0.015 \\
THIOLS $(\mathrm{mmol} / \mathrm{L})$ and WBC $\left(\times 10^{9} / \mathrm{L}\right)$ & $-0.943^{6}(-0.994$ to -0.559$)$ & 0.005 \\
HPT $(\mathrm{mg} / \mathrm{dL})$ and HGB $(\mathrm{g} / \mathrm{L})$ & $0.829^{6}(0.052$ to 0.981$)$ & 0.042 \\
$\quad$ Recovery & & \\
GPx $(\mu \mathrm{Kat} / \mathrm{g} \mathrm{Hgb})$ and MDA $(\mu \mathrm{mol} / \mathrm{g} \mathrm{Hgb})$ & $0.964^{7}(0.771$ to 0.995$)$ & $<0.001$ \\
GPx $(\mu \mathrm{Kat} / \mathrm{g} \mathrm{Hgb})$ and CAT $(\mathrm{U} / \mathrm{g} \mathrm{Hgb})$ & $0.786^{7}(0.080$ to 0.967$)$ & 0.036 \\
THIOLS $(\mathrm{mmol} / \mathrm{L})$ and LYM $\left(\times 10^{9} / \mathrm{L}\right)$ & $0.881^{7}(0.465$ to 0.978$)$ & 0.004 \\
$\quad$ Relative change $(\%)$ & & 0.014 \\
GPx and MDA & $0.857^{7}(0.294$ to 0.979$)$ & 0.005 \\
THIOLS and RBC & $0.943^{6}(0.559$ to 0.994$)$ & 0.019 \\
\hline THIOLS and HGB & $0.886^{6}(0.264$ to 0.987$)$ & \\
\hline
\end{tabular}

Abbreviations: CAT, catalase; CER, ceruloplasmin; GPx, glutathione peroxidase; HGB, concentration of hemoglobin in whole blood; Hgb, hemoglobin in hemolysates; HPT, haptoglobin; LYM, lymphocytes; MDA, malondialdehyde; RBC, red blood cells; THIOLS, free thiol groups; WBC, white blood cells. 

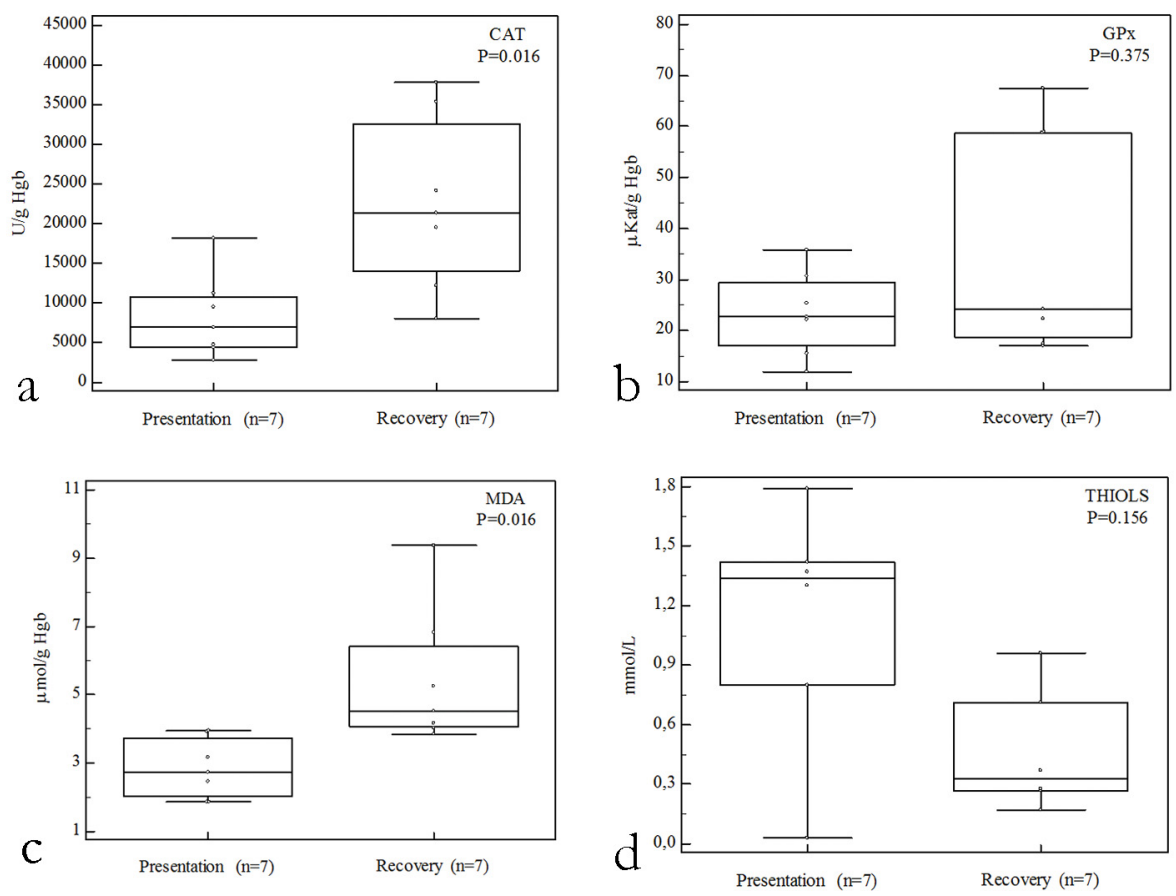

Figure 3. Activity of (A) catalase (CAT), (B) glutathione peroxidase (GPx) and (C) concentration of malondialdehyde (MDA) in RBCs, and (D) concentration of free thiol groups (THIOLS) in sera samples. Wilcoxon test, $\mathrm{P}<0.05$ is considered significant. Box represents values from lower to upper quartile. The middle line in the box represents the median. A line extends from the minimum to maximum value.

When the dogs successfully recovered, a strong positive correlation between GPx activity and MDA concentration in RBCs persisted. Also, additional positive correlations appeared at that point: between GPx and CAT activities in RBCs, and serum THIOLS and lymphocyte count (Table 1).

Analysis of relative changes between presentation and recovery data revealed strong positive correlations between the GPx activity and MDA concentration in RBCs, serum THIOLS concentration and RBC count, as well as serum THIOLS and HGB concentration in the whole blood (Table 1).

\section{DISCUSSION}

Our results provide a reliable evidence about a comprehensive relationship between simultaneous changes in hematological parameters, APPs levels and redox homeostasis during acute canine babesiosis. At presentation, anemia, low/normal leukocyte count and severe thrombocytopenia occurred together with increased or decreased levels of APPs and compromised the antioxidative defense. After a successful treatment, hematological values generally fitted within the reference interval, APPs were within 
physiological levels in the majority of cases and the activities of the antioxidant enzymes increased. However, RBC oxidative damage remained as a deleterious sequel despite the successful clinical recovery of the dogs.

Recovery from anemia is a well-recognized feature of a favorable outcome during the treatment of canine babesiosis [17]. Nevertheless, we showed that during this process a specific pattern in the redox homeostasis occurs in RBCs: concomitant increase in CAT activity and MDA levels. These results suggest that at the moment of dogs' acute inflammation due to $B$. canis infection, intraerythrocytic oxidative stress existed, but CAT, GPx and presumably other antioxidant defense mechanisms protected RBCs from oxidative injury and hemolysis. However, 15 days later, after successful treatment and clinical recovery, RBCs count returned to the reference interval and MDA values were higher compared to presentation. RBCs analyzed at presentation were the ones that were not destroyed due to B. canis infection. Within the mentioned 15 days, bone marrow released young, newly maturated RBCs, which made nearly half of the circulating pool at recovery. Thus, RBCs analyzed at recovery, due to relatively long RBC lifespan in dogs [18], contained half of "old" RBCs and half of "young" RBCs. These "old" RBCs had diminished antioxidant defense due to the precedent acute infection and inflammation, and probably succumbed to oxidative stress. Furthermore, several positive correlations (between the relative changes of GPx and MDA, THIOLS and $\mathrm{RBC} / \mathrm{HGB}$, as well as between GPx and MDA at recovery) underpin this explanation. It is interesting to note that many studies indicated an increased degree of lipid peroxidation and serum MDA levels in animals with babesiosis [4,8,29], but none of these studies extended the research far enough to be able to compare the same animals when anemic and at the moment of clinical recovery.

The dynamics in the levels of APPs and rather stable level of THIOLS ascertained that the antioxidant system in the serum retained the efficiency during the clinical course of acute canine babesiosis. The level of CER, an APP that dismutes superoxide anion and lipid peroxides decreased as the dogs recovered [30,31]. The opposite changes appeared in the activity of PON-1, an enzyme that auto-inactivates while neutralizing ROS [32]. Additionally, the decrease in serum THIOLS between presentation and recovery was not significant. These changes imply that ROS were also present in plasma, and probably were successfully neutralized by the mutual activity of CER, PON-1 and other plasma antioxidant defense mechanisms.

The absence of a significant difference in the concentration of HPT between presentation and recovery can represent an indirect evidence of hemolytic component in the pathogenesis of babesiosis [33]. At presentation HPT level represented the equilibrium between the higher production in hepatocytes, as it belongs to positive APPs [17] and consumption due to a certain degree of hemolysis. The strong positive correlation between HPT in the serum and HGB in the whole blood may support this explanation. The effective scavenging of free HGB is one of the crucial mechanisms in antioxidant protection, as the free heme is one of the generators of ROS in plasma 
[34,35]. When recovery occurred, the process became reverse: both hepatic synthesis and intravascular consumption decreased.

Besides free heme, ROS production during inflammation also stems from activated neutrophil granulocytes and monocytes [10,11]. Indeed, it was shown that at presentation, the levels of THIOL groups in the serum are highly negatively correlated with the total leukocyte count pointing to the contribution of leukocytes in ROS generation. Our results are in accordance with other studies demonstrating that reduced thiol levels are a consequence of parasitic diseases [36,37]. At recovery, THIOL groups were in a positive correlation with lymphocytes count. However, this feature cannot be easily explained and thus warrant further investigation.

The small number of dogs represents a potential limitation of the study. Nevertheless, the obtained results show unambiguous potential to further elucidate molecular pathways during the clinical course of acute canine babesiosis. As such, they are eligible for further verification in larger cohorts.

\section{CONCLUSION}

Simultaneous and related changes in hematological parameters, levels of APPs and redox homeostasis mirrored the clinical course of the acute infection with B. canis. The majority of these changes evidenced an effective therapeutic response. Nevertheless, some of them indicated development of subtle molecular and cellular oxidative defects despite the successful clinical recovery, which challenge the necessity for a longer follow-up period and eventual therapeutic fortification with antioxidants.

\section{Acknowledgements}

Vladimir Radonjić, DVM (Petrovac, small animal veterinary practice, Belgrade), Milica Ilić, DVM (Filipović, small animal veterinary practice, Belgrade) and students Maša Ivković and Milica Stanić (Faculty of Veterinary Medicine, University of Belgrade) provided devoted assistance in collecting samples for this study. Phyllis Tyrrell and Ramaswamy Chandrashekar (IDEXX Laboratories, Inc., Westbrook, ME, USA) performed real-time PCR analysis. The study was supported by the Ministry of

Education, Science and Technological Development of the Republic of Serbia (Contract number: 451-03-9/2021-14/200143).

\section{Author's contribution}

MKF and SM designed the study. KS and FJ collected the samples. KS, MR, FJ and JFA performed the laboratory analyses. $\mathrm{AB}$ performed and interpreted the statistical analyses. $\mathrm{KS}, \mathrm{MR}, \mathrm{AB}, \mathrm{MKF}$ and $\mathrm{SM}$ interpreted the data and equally contributed in the writing of the manuscript. All authors have read and approved the manuscript. 


\section{Declaration of conflicting interests}

The author(s) declared no potential conflicts of interest with respect to the research, authorship, and/or publication of this article.

\section{Statement of Informed Consent}

The owner understood procedure and agrees that results related to investigation or treatment of their companion animals, could be published in Scientific Journal Acta Veterinaria-Beograd.

\section{REFERENCES}

1. Irwin PJ: Canine babesiosis: from molecular taxonomy to control. Parasites Vectors 2009, 2:S4.

2. Boozer LA, Macintire DK: Canine babesiosis. Vet Clin North Am Small Anim Pract 2003, 33:885-904.

3. Otsuka Y, Yamasaki M, Yamato O, Maede Y: Increased generation of superoxide in erythrocytes infected with Babesia gibsoni. J Vet Med Sci 2001, 63:1077-1081.

4. Saleh M: Erythrocytic oxidative damage in crossbred cattle naturally infected with Babesia bigemina. Res Vet Sci 2009, 86:43-48.

5. Kumar B, Mondal DB, Jithin MV: Evaluation of reactive oxidative damage on erythrocytic cells due to clinical babesiosis in lactating cows. Int J Livest Res 2019, 9:55-64.

6. Nazifi S, Razvi SM, Kianiamin P, Rakhshandehroo E: Evaluation of erythrocyte antioxidant mechanisms: antioxidant enzyme lipid peroxidations and serum trace element associated with progressive anemia in ovine malignant theileriosis. Parasitol Res 2011, 2:275-81.

7. Murase, T, Ueda T, Yamato O, Tajima M, Maede Y: Oxidative damage and enhanced erythrophagocytosis in canine erythrocytes infected with Babesia gibsoni. J Vet Med Sci 1996, 58:259-261.

8. Crnogaj M, Cerón JJ, Šmit I, Kiš I, Gotić J, Brkljačić M, Matijatko V, Rubio CP, Kučer N, Mrljak V: Relation of antioxidant status at admission and disease severity and outcome in dogs naturally infected with Babesia canis canis. BMC Vet Res 2017, 13:114.

9. Cray C, Zaias J, Altman NH: Acute phase response in animals: A review. Comp Med 2009, 59:517-526.

10. Winterbourn C, Kettle AJ, Hampton MB: Reactive oxygen species and neutrophil function. Annu Rev Biochem 2016, 85:765-792.

11. Gougerot-Pocidalo MA, Roche Y, Fay M, Perianin A, Bailly S: Oxidative injury amplifies interleukin-1-like activity produced by human monocytes. Int J Immunopharmacol 1989, 11:961-969.

12. Fox PL, Mukhopadhyay C, Ehrenwald E: Structure, oxidant activity, and cardiovascular mechanisms of human ceruloplasmin. Life Sci 1995, 56:1749-1758.

13. Ceron JJ, Tecles F, Tvarijonaviciute A: Serum paraoxonase 1 (PON-1) measurement: an update. BMC Vet Res 2014, 10:74. 
14. Lim SK, Ferraro B, Moore K, Halliwell B: Role of haptoglobin in free hemoglobin metabolism. Redox Rep 2001, 6:219-227.

15. Beletić A, Janjić F, Radaković M, Spariosu K, Francuski Andrić J, Chandrashekar R, Tyrrell P, Radonjić V, Balint B, Ajtić J, Kovačević Filipović M: Systemic inflammatory response syndrome in dogs naturally infected with Babesia canis: Association with parasite load and host factors. Vet Parasitol 2021, 291:109366.

16. Milanović Z, Beletić A, Vekić J, Zeljković A, Andrić N, Ilić Božović A, Spariosu K, Radaković M, Ajtić J, Kovačević Filipović M: Evidence of acute phase reaction in asymptomatic dogs naturally infected with Babesia canis. Vet Parasitol 2020, 282:109140.

17. Matijatko V, Mrljak V, Kiš I, Kučer N, Foršek J, Živičnjak T, Romić Ž, Simec Z, Ceron JJ: Evidence of an acute phase response in dogs naturally infected with Babesia canis. Vet Parasitol 2007, 144:242-250.

18. Hawkins WB, Whipple GH: The life cycle of the red blood cell in the dog. Am J Phisiol 1938, 122:418-427.

19. Milanović Z, Vekić J, Radonjić V, Ilić Božović A, Zeljković A, Janac J, Spasojević Kalimanovska V, Buch J, Chandrashekar R, Bojić Trbojević Ž, Hajduković Lj, Christopher MM, Kovačević Filipović M: Association of acute Babesia canis infection and serum lipid, lipoprotein, and apoprotein concentrations in dogs. J Vet Intern Med 2019, 33:1686-1694.

20. Ceron JJ, Martinez-Subiela S. An automated spectrophotometric method for measuring canine ceruloplasmin in serum. Vet Res 2004, 35:671-679.

21. Owen JA, Better FC, Hoban J: A simple method for the determination of serum haptoglobins. J Clin Pathol 1960, 13:163-164.

22. Jones GE, Mould DL: Adaptation of the guaiacol (peroxidase) test for haptoglobins to a microtitration plate system. Res Vet Sci 1984, 37:87-92.

23. Dantoine TF, Debord J, Charmes JP, Merle L, Marquet P, Lachatre J, Leroux-Robert C: Decrease of serum paraoxonase activity in chronic renal failure. J Am Soc Nephrol 1998, 9:2082-2088.

24. Van Kampen EJ, Zijlstra WG: Standardization of hemoglobinometry II. The hemiglobincyanide method. Clin Chim Acta 1961, 6:538-544.

25. Aebi H: Catalase in vitro. In: Methods in Ensymology. Orlando, USA: Academic Press; 1984, 121-126.

26. Günzler WA, Kremers H, Flohe L: An improved coupled test procedure for glutathione peroxidase (E.C. 1.11.1.9) in blood. Z Klin Chem Klin Biochem 1974, 12:444.

27. Girotti MJ, Khan N, McLellan BA: Early measurement of systemic lipid peroxidation products in the plasma of major blunt trauma patients. J Trauma Acute Care Surg 1991, 31:32-35.

28. Ellman E: Tissue sulfhydryl groups. Arch Biochem Biophys 1959, 82:70-77.

29. Salem N, Yehia S, Farag H, Awny Elkhia M: Clinical, hemato-biochemical alterations and oxidant-antioxidant biomarkers in Babesia-infected calves. Int J Vet Sci Med 2016, 4:17-22.

30. Goldstein IM, Kaplan HB, Edelson HS, Weissmann G: Ceruloplasmin: a scavenger of superoxide anion radicals. J Bio Chem 1979, 254:4040-4045.

31. Gutteridge JMC, Stocks J: Caeruloplasmin: physiological and pathological perspective. CRC Crit Rev Clin Lab Sci 1981, 14:257-329.

32. James RW: A long and winding road: defining the biological role and clinical importance of paraoxonases. Clin Chem Lab Med 2006, 44:1052-1059. 
33. Reyers, F, Leisewitz, AL, Lobetti, RG, Milner, RJ, Jacobson, LS: Canine babesiosis in South Africa: more than one disease. Does this serve as a model for falciparum malaria? Ann Trop Med Parasitol 1998, 92, 503-511.

34. Hasan RN, Schafer AI: Hemin upregulates Egr-1 expression in vascular smooth muscle cells via reactive oxygen species ERK-1/2-Elk-1 and NF-kB. Circ Res 2008, 102:42-50.

35. Duvigneau JC, Esterbauer H, Kozlov AV: Role of heme oxygenase as a modulator of heme-mediated pathways. Antioxidants (Basel) 2019, 8:475.

36. Radaković M, Davitkov D, Borozan S, Stojanović S, Stevanović J, Krstić V, Stanimirović Z: Oxidative stress and DNA damage in horses naturally infected with Theileria equi. Vet J 2016, 217:112-118.

37. Rubio CP, Martinez-Subiela S, Tvarijonaviciute A, Hernández-Ruiz J, Pardo-Marin L, Segarra S, Ceron JJ: Changes in serum biomarkers of oxidative stress after treatment for canine leishmaniosis in sick dogs. Comp Immunol Microbiol Infect Dis 2016, 49:51-57.

\title{
POVEZANOST PROMENA HEMATOLOŠKIH PARAMETARA, NIVOA PROTEINA AKUTNE FAZE I REDOKS HOMEOSTAZE TOKOM AKUTNE INFEKCIJE PASA SA BABESIA CANIS
}

\author{
Kristina SPARIOSU, Filip JANJIĆ, Jelena FRANCUSKI ANDRIĆ, \\ Milena RADAKOVIĆ, Anđelo BELETIĆ, Milica KOVAČEVIĆ FILIPOVIĆ, \\ Svetlana MILANOVIĆ
}

Babezioza pasa, koju izaziva protozoa Babesia canis, praćena je hemolizom i sistemskom akutnom inflamacijom. Naša hipoteza je da kod pasa sa akutnom B. canis infekcijom, čak i nakon terapije imidokarb-dipropionatom i uspešnog kliničkog oporavka, postoji poremećaj redoks homeostaze. Studija uključuje osam vlasničkih pasa akutno inficiranih babezijom. Analizirani su kompletna krvna slika, proteini akutne faze (ceruloplazmin, haptoglobin i paraoksonaza-1) u serumu, antioksidativni enzimi (katalaza i glutation peroksidaza) u eritrocitima i markeri oksidativnog stresa (malondialdehid u eritrocitima, tiolne grupe u serumu) na prezentaciji i 15 dana nakon terapije. Za procenu značajnosti rezultata primenjeni su odgovarajući statistički testovi. Anemija, nizak/normalan broj leukocita i teška trombocitopenija praćeni povišenom koncentracijom ceruloplazmina, haptoglobinom u fiziološkim intervalima i sniženim nivoom paraoksonaze-1, kao i kompromitovana antioksidativna zaštita, uočeni su na prezentaciji. Nakon terapije i uspešnog kliničkog oporavka, hematološke vrednosti su bile u fiziološkom opsegu, kao i proteini akutne faze kod većine pacijenata, a aktivnost antioksidativnih enzima je pojačana. Međutim, povišena koncentracija malondialdehida ukazuje na povećano oštećenje eritrocita koje je zaostalo uprkos uspešnom kliničkom oporavku pasa. 